Article

\title{
Comparison of Antioxidant Capability after Isopropanol Salting-Out Pretreatment and $n$-Butanol Partition Extraction, and Identification and Evaluation of Antioxidants of Sedum formosanum N.E.Br.
}

\author{
Jung-Hui Chen ${ }^{1, *}$, Wen-Hui Lai ${ }^{2,+}$, Shang-Dung Lin ${ }^{2,+}$, Cheng-Fong Lan ${ }^{2,+}$, Shih-Lan Hsu ${ }^{3,+}$ \\ and Ming-Yuan Liao ${ }^{2, *}$ \\ 1 Department of Mechanical Engineering, Nan-Kai University of Technology, 568 ZhongZheng Road, Caotun, \\ Nantou County 542, Taiwan \\ 2 Department of Chemistry, National Chung Hsing University 250 Kuo-Kuang Road, Taichung 402, Taiwan; \\ David751008@gmail.com (W.-H.L.); gloom2007@hotmail.com (S.-D.L.); mark921117@gmail.com (C.-F.L.) \\ 3 Department of Medical Research, Taichung Veterans General Hospital, 1650 Taiwan Road Sec, Taichung 402, \\ Taiwan; h2326@vghtc.gov.tw \\ * Correspondence: t115@nkut.edu.tw (J.-H.C.); mliao@dragon.nchu.edu.tw (M.-Y.L.); \\ Tel.: +886-49-256-3489 (ext. 2390) (J.-H.C.); +886-4-2284-0411 (ext. 626) (M.-Y.L.); \\ Fax: +886-49-256-7424 (J.-H.C.); +886-4-2286-2547 (M.-Y.L.) \\ + These authors contributed equally to this work.
}

Academic Editor: Maurizio Battino

Received: 16 February 2016; Accepted: 13 April 2016; Published: 19 April 2016

\begin{abstract}
Crude extracts of Sedum formosanum N.E.Br. obtained from $n$-butanol partition (BP) and isopropanol salting-out pretreatment (ISP) were analyzed using antioxidation assays. The results indicated that the extract from ISP contained more potent antioxidants and thus exhibited more antioxidant activity in all the assays. The superoxide radical-scavenging activity and inhibition of nitric oxide radicals achieved after ISP were 3.65 and 2.18 times higher than those achieved through $\mathrm{BP}$, respectively. Eight bioactive natural products were isolated and identified according to an analysis of antioxidation activity in different fractions of the ISP crude extract, namely three cyanophoric glycosides 1-3, three flavonoids 4-6 and two phenolic compounds (7 and a new compound 8). Among them, compounds $\mathbf{5}$ and $\mathbf{6}$ exhibit the highest antioxidation capability, and the ISP is suitable for obtaining compounds 5 and $\mathbf{6}$ using HPLC chromatograms. Therefore, ISP is an excellent extraction technology that can be used to extract antioxidant compounds in the nutraceutical and pharmaceutical industries.
\end{abstract}

Keywords: S. formosanum N.E.Br.; salting-out; cyanophoric glycoside; flavonoids; antioxidant activity

\section{Introduction}

In the human body, the normal oxidative metabolism constantly produces reactive oxygen species (ROSs), such as hydrogen peroxide, superoxide $\left(\mathrm{O}_{2} \cdot{ }^{-}\right)$, the hydrogen radical $(\cdot \mathrm{OH})$, singlet oxygen, and nitrogen species. In vivo, through an endogenous antioxidant defense mechanism comprising antioxidant enzymes, such as superoxide dismutase, catalase, and glutathione peroxidase, are firmly coupled at their generation site or are detoxified, possibly preserving optimal cellular function [1]. However, under pathological conditions, detoxifying mechanisms are often inadequate, possibly producing excessive quantities of ROS. Oxidative stress is a pro-oxidant shifting process that can degrade cellular components, such as DNA, carbohydrates, polyunsaturated lipids, and proteins. Furthermore, upsetting the pro-oxidant-antioxidant balance generates oxidative stress. This oxidative stress can cause enzyme inactivation, irreversible cellular dysfunction, and cell death [2]. Antioxidant 
compounds can inhibit the initiation or propagation of oxidation chain reactions and delay or inhibit the oxidation of lipids or other molecules. Therefore, antioxidant compounds have received increasing attention regarding their ability to prevent or repair oxidative damage [3]. Because chemically produced analogs are reported carcinogens, natural antioxidants are likely to be acceptable to users [4].

The phytochemicals of plants are potential sources of natural antioxidants, including phenolic compounds, flavonoids, alkaloids, and terpenoids [5]. In particular, flavonoids and phenolic compounds are highly effective antioxidants that possess anticancer, hypolipidemic, anti-aging, and anti-inflammatory properties; thus, they have received increasing attention [6]. Moreover, flavonoids can protect biological systems by scavenging free radicals, chelating metal catalysts, activating antioxidant enzymes, reducing $\alpha$-tocopherol radicals, and inhibiting oxidase capability [7]. Flavonoids are biodegradable and non-toxic, and they may be an appealing alternative to currently available commercial synthetic antioxidants [8].

The genus Sedum (Crassulaceae), a medicinal plant, grows mainly in various Eastern-European regions and on mountain slopes in China and South Korea, and numerous Sedum species are used pharmaceutically. Sedum kamtschoticum Fischer is a perennial common in South Korea, China, and Japan. Its water extracts have been used in folk medicine, particularly as anti-anxiety, anti-inflammation, and analgesic agents and for improving blood circulation [9]. Sedum dendroideum Moc \& Sessé is widely used to treat ulcers, inflammation, and wounds in Brazil and other parts of the world [10]. Sedum telephium possesses local anti-inflammatory activity and is presently used throughout Europe for healing wounds and treating various types of local inflammation [11]. Rhodiola quadrifida (PAll) Fish. et Mey is prescribed for hemostatic, antibechic, and tonic uses in Chinese medicine, is used for preparing endermic liniments for burns and contusions, and was shown to possess antiallergic activity in rats in a passive cutaneous anaphylaxis test [12]. Sedum sarmentosum is a type of folk medicine that has been used to treat chronic viral hepatitis in China and South Korea. The plant granules have been used in the clinic since 1971 [13], and inhibit oleic-acid-albumin-induced lipid accumulation in HepG2 cells [14]. Furthermore, this herb improves the survival of hepatoma patients by inhibiting excessive tumor cell growth [15]. In previous phytochemical studies on the Sedum species, several compounds have been isolated, such as alkaloids, tannins, flavonoids, megastigmene, and cyanogenic compounds [16-18]. S. formosanum N.E.Br. is a perennial herbaceous plant that grows mainly in wetlands, coastal areas, or seams of rock and gravel. Although S. formosanum is widely distributed in Asia, the components responsible for the antioxidant activity of $S$. formosanum have not been explored in detail. Therefore, further research must be performed to isolate and identify these plant extract components for nutraceutical and pharmaceutical applications.

This study was performed in three parts. First, we evaluated the antioxidant activity of the crude extracts of $S$. formosanum N.E.Br. obtained by using isopropanol salting-out pretreatment (ISP) and $n$-butanol partition (BP) extraction technology. Next, we isolated and identified the major compounds from the previous crude extracts and evaluated their antioxidant activity by using different antioxidant assays. In the final stage, we compared the chromatograms of the crude extracts obtained with the ISP and BP technology, and demonstrated that the hydrophilic ISP extraction technology is superior to the BP extraction technology for promoting antioxidant extraction. The antioxidant-promotion capability, such as the chelation of ferrous as well as nitric oxide (NO) and superoxide anion radical scavenging activity, were compared between the ISP and SP extraction technology for the first time. The purpose of this study was to confirm the value of the ISP extraction technology and to prove that this technology can be universally applied for extracting and isolating natural plants for nutraceutical and pharmaceutical applications. 


\section{Results and Discussion}

\subsection{Comparison of the Antioxidant Capability of n-Butanol Partition and Isopropanol Salting-Out Pretreatment Extraction Technology}

Table 1 displays the antioxidant capability results after use of the ISP and BP extraction technology, which were obtained using assays on superoxide radical-scavenging activity, oxygen radical absorbance capacity (ORAC) radical-scavenging activity, chelation of ferrous ions, and inhibition of NO radical activity. The antioxidant activity of the crude extract is expressed in micromoles of Trolox equivalent (TE) per gram of dried materials. After statistical calculation, the $t$-test values are 2.442, 43.268, 15.08 and 22.624 for FRAP, SOD, NO and ORAC, respectively. Therefore, the antioxidant capability comparison of the ISP and BP extractions possesses statistical significance. The results indicated that the antioxidant capability of the crude extract from the ISP extraction technology was between 3.65 and 1.38 times higher than that of the crude extract obtained by the BP extraction technology. The superoxide radical-scavenging activity and inhibition of the NO radical obtained using ISP extraction technology were respectively 3.65 and 2.18 times higher than those obtained using BP extraction technology ( 0.21 vs. 0.057 micromoles of TE/g; 0.118 vs. 0.054 micromoles of TE/g, respectively). These data suggest that ISP extraction technology is preferable to BP extraction technology for extracting antioxidants. Consequently, isolating and evaluating the antioxidant capability of the pure compounds of S. formosanum N.E.Br. by using ISP extraction technology is significant.

Table 1. Results of the different free radical scavenging capacities obtained using the isopropanol salting-out and $n$-butanol partition extraction methods for Sedum formosanum N.E.Br. Values represent means $\pm \operatorname{SD}(n=3)$.

\begin{tabular}{|c|c|c|c|c|}
\hline \multirow[b]{2}{*}{ Extraction Method } & \multicolumn{2}{|c|}{ Isopropanod Salting-Out Extraction Method } & \multicolumn{2}{|c|}{ Butanol Partition Extraction Method } \\
\hline & $\begin{array}{l}\text { Average Cleaning } \\
\text { Factor }(\%)\end{array}$ & $\begin{array}{l}\text { Equivalent to Trolox } \\
\text { (mmol/g) a }\end{array}$ & $\begin{array}{l}\text { Average Cleaning } \\
\text { Factor }(\%)\end{array}$ & $\begin{array}{c}\text { Equivalent to } \\
\text { Trolox }(\mathrm{mmol} / \mathrm{g})^{\text {a }}\end{array}$ \\
\hline${ }^{b}$ FRAP & 31.85 & $0.071 \pm 0.011$ & 21.60 & $0.052 \pm 0.005$ \\
\hline${ }^{\mathrm{c}} \mathrm{SOD}$ & 77.96 & $0.210 \pm 0.005$ & 20.41 & $0.057 \pm 0.007$ \\
\hline $\mathrm{d}^{\mathrm{NO}}{ }^{*}$ scavenging & 57.48 & $0.118 \pm 0.006$ & 25.27 & $0.054 \pm 0.007$ \\
\hline e ORAC & 70.56 & $0.198 \pm 0.005$ & 57.83 & $0.118 \pm 0.005$ \\
\hline
\end{tabular}

a $(\mathrm{mmol} / \mathrm{g})$ : are expressed micromoles of Trolox equivalent to per gram of the test dried materials weight.

${ }^{b}$ FRAP: Ferrous ion chelating activity. ${ }^{c}$ SOD: Superoxide anion radical scavenging activity. ${ }^{d} \mathrm{NO}^{*}$ scavenging: Nitric Oxide radical scavenging activity. ${ }^{e}$ ORAC: Oxygen Radical Absorption Capacity

\subsection{Identification of Compounds 1-8 Using Isopropanol Salting-Out Pretreatment Extraction Technology}

Three cyanophoric glycosides, three flavonoids, and two phenolic compounds were isolated from $S$. formosanum N.E.Br by using isopropanol salting-out extraction technology. Their structures were determined as rhodiocyanoside A (1), rhodiocyanoside D (2), sarmentosin (3), kaempferol-3-O- $\beta$ D-glucopyranoside (4), kaempferol-3,7-di-O- $\beta$-D-glucopyranoside (5), vicenin-2 (6), gastrodin (7), and cis- $p$-coumaric acid-4- $\beta$-O-L-glucopyranosyl-( $1 \rightarrow 3)$ - $\alpha$-L-rhamnopyranoside methyl ester (8). Compound 8 is a new compound, whereas compounds 1, 2, 3, 5, 6 and 7 were identified for the first time from $S$. formosanum N.E.Br. Their structures are shown in Figure 1.

The molecular formula of compound 8 is $\mathrm{C}_{22} \mathrm{H}_{30} \mathrm{O}_{12}$ deduced from HR-FT-MS ( $[\mathrm{M}+\mathrm{H}]^{+} \mathrm{m} / z$ : 487.1812). The IR spectrum of compound 8 revealed the presence of the hydroxyl group $\left(3362 \mathrm{~cm}^{-1}\right)$ and $\alpha, \beta$-unsaturated ester $\mathrm{C}=\mathrm{O}$ group $\left(1660 \mathrm{~cm}^{-1}\right)$. The ${ }^{1} \mathrm{H}-\mathrm{MNR}$ and ${ }^{1} \mathrm{H}$-COSY spectra (Table 2 and Figure 2) suggest the presence of a para-substituted phenyl ring, $\mathrm{A}_{2} \mathrm{~B}_{2}$ protons at $\delta 7.05(\mathrm{~d}$, $\left.J=8.7 \mathrm{~Hz}, \mathrm{H}_{2,6}\right)$ and $\delta 7.66\left(\mathrm{~d}, J=8.7 \mathrm{~Hz}, \mathrm{H}_{3,5}\right)$, two single protons coupled to double doublets $\delta$ $6.92(\mathrm{~d}, J=12.5 \mathrm{~Hz}, \mathrm{H}-7)$ and $\delta 5.87(\mathrm{~d}, J=12.5 \mathrm{~Hz}, \mathrm{H}-8)$, in which $J=12.5 \mathrm{~Hz}$ is the cis-form. One methoxyl group at $\delta 3.70(3 \mathrm{H}, \mathrm{s})$ and in conjunction with the ${ }^{13} \mathrm{C}-\mathrm{NMR}$ signals at $158.4\left(\mathrm{C}_{1}\right), 116.8$ $\left(\mathrm{C}_{2,6}\right), 133\left(\mathrm{C}_{3,5}\right), 129.4\left(\mathrm{C}_{4}\right), 144.2\left(\mathrm{C}_{7}\right), 118.2\left(\mathrm{C}_{8}\right), 165.8\left(\mathrm{C}_{9}\right)$ and $51.8\left(\mathrm{C}_{10}\right)$ indicated that compound 8 is cis-p-coumaric acid methyl ester. The ${ }^{1} \mathrm{H}-\mathrm{NMR}$ and ${ }^{13} \mathrm{C}-\mathrm{NMR}$ spectra of compound 8 revealed the presence of a $\alpha$-L-rhamnopyranosyl moiety $\left[\delta_{\mathrm{H}} 5.51\left(\mathrm{~d}, J=1.8 \mathrm{~Hz}, \mathrm{H}-1^{\prime}\right)\right.$ and $\delta \mathrm{c} 99.3,71.2,82.5$, 
72.5, and 18.1] and a $\beta$-D-glucopyranosyl moiety [ $\delta 4.60\left(\mathrm{~d}, J=7.5 \mathrm{~Hz}, \mathrm{H}-1^{\prime \prime}\right)$ and $\delta \mathrm{c} 105.9,72.3$, $77.7,72.6,77.8$, and 62.0]. In HMBC experiment, between the H-1" of the D-glucose and the C-3' of the L-rhamnose, between the $\mathrm{H}_{-1}{ }^{\prime}$ of the L-rhamnose and the C-1 of compound 8 , and between the $\mathrm{H}$ of methoxyl and the C-9 of compound 8 had long-range correlation (Figure 2) and assignment confirmed by decoupling, ${ }^{1} \mathrm{H}-{ }^{1} \mathrm{H}$ COSY, HMQC and HMBC. Hence, compound 8 was elucidated to be cis-p-coumaric acid-4- $\beta$-O-L-glucopyranosyl-( $1 \rightarrow 3)$ - $\alpha$-L-rhamnopyranoside methyl ester.<smiles>C/C(C#N)=C\CO[C@H]1O[C@H](CO)[C@@H](O)[C@H](O)[C@H]1O</smiles>

1<smiles>N#C/C(=C\CO[C@@H]1O[C@H](CO)[C@@H](O)[C@H](O)[C@H]1O)CO</smiles>

3<smiles>O=c1c(O[C@@H]2O[C@H](CO)[C@@H](O)[C@H](O)[C@H]2O)c(-c2ccc(O)cc2)oc2cc(O[C@@H]3O[C@H](CO)[C@@H](O)[C@H](O)[C@H]3O)cc(O)c12</smiles>

5<smiles>OCc1ccc(O[C@@H]2O[C@H](CO)[C@@H](O)[C@H](O)[C@H]2O)cc1</smiles>

7<smiles>C/C(C#N)=C\CO[C@@H]1O[C@H](CO)[C@@H](O)[C@H](O)[C@H]1O</smiles><smiles>O=c1c(O[C@@H]2O[C@H](CO)[C@@H](O)[C@H](O)[C@H]2O)c(-c2ccc(O)cc2)oc2cc(O)cc(O)c12</smiles>

4<smiles>O=c1cc(-c2ccc(O)cc2)oc2c([C@H]3O[C@H](CO)[C@@H](O)[C@H](O)[C@H]3O)c(O)c(C3O[C@H](CO)[C@@H](O)[C@H](O)[C@H]3O)c(O)c12</smiles>

6

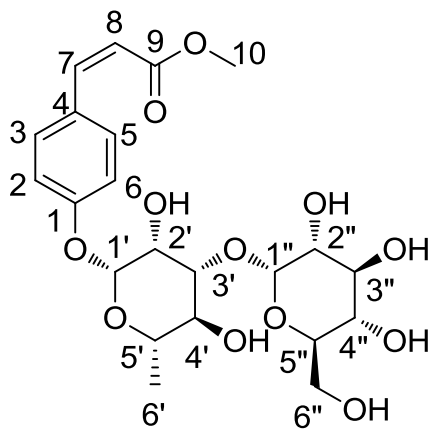

8

Figure 1. Chemical structures of compounds 1, 2, 3, 4, 5, 6, 7 and 8 . 
<smiles>COC(=O)/C=C\c1ccc(O[C@@H]2O[C@H](C)[C@@H](O)[C@H](OC3O[C@H](CO)[C@@H](O)[C@H](O)[C@H]3O)[C@H]2O)cc1</smiles>

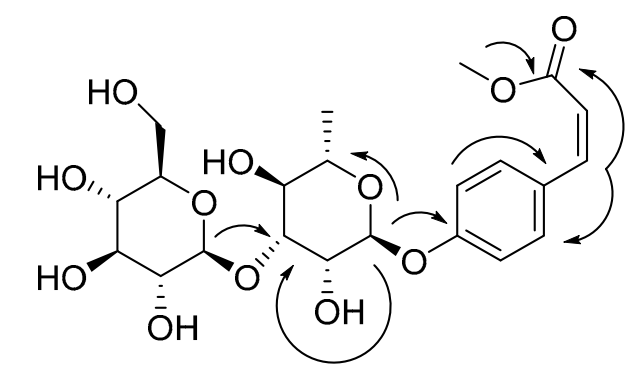

Figure 2. ${ }^{1} \mathrm{H}_{-}{ }^{1} \mathrm{H}$ COSY and HMBC correlation of compound 8.

Table 2. ${ }^{1} \mathrm{H}-\mathrm{NMR}(400 \mathrm{MHz})$ spectra and ${ }^{13} \mathrm{C}-\mathrm{NMR}(100 \mathrm{MHz})$ spectra of compound 8.

\begin{tabular}{|c|c|c|}
\hline \multirow{2}{*}{ Position } & \multicolumn{2}{|c|}{ Compound 8 (in $\mathrm{CD}_{3} \mathrm{OD}$ ) } \\
\hline & ${ }^{1} \mathrm{H}(\delta)(\mathrm{ppm})$ & ${ }^{13} \mathrm{C}(\delta)(\mathrm{ppm})$ \\
\hline 1 & & 158.4 \\
\hline 2 & $7.06(1 \mathrm{H}, \mathrm{d}, J=8.8 \mathrm{~Hz})$ & 116.4 \\
\hline 3 & $7.67(1 \mathrm{H}, \mathrm{d}, J=8.8 \mathrm{~Hz})$ & 132.7 \\
\hline 4 & & 130.9 \\
\hline 5 & $7.67(1 \mathrm{H}, \mathrm{d}, J=8.8 \mathrm{~Hz})$ & 132.7 \\
\hline 6 & $7.06(1 \mathrm{H}, \mathrm{d}, J=8.8 \mathrm{~Hz})$ & 116.4 \\
\hline 7 & $6.93(1 \mathrm{H}, \mathrm{d}, J=12.8 \mathrm{~Hz})$ & 144.2 \\
\hline 8 & $5.88(1 \mathrm{H}, \mathrm{d}, J=12.8 \mathrm{~Hz})$ & 117.8 \\
\hline 9 & & 168.3 \\
\hline 10 & $3.66(3 \mathrm{H}, \mathrm{s})$ & 51.8 \\
\hline \multicolumn{3}{|l|}{ Rha } \\
\hline $1^{\prime}$ & $5.51(1 \mathrm{H}, \mathrm{d}, J=1.8 \mathrm{~Hz})$ & 99.4 \\
\hline $2^{\prime}$ & $4.30(1 \mathrm{H}, \mathrm{m})$ & 71.3 \\
\hline $3^{\prime}$ & $3.97(1 \mathrm{H}, \mathrm{m})$ & 82.7 \\
\hline $4^{\prime}$ & $3.95^{\mathrm{a}}(1 \mathrm{H}, \mathrm{m})$ & 72.6 \\
\hline $5^{\prime}$ & $3.67^{\mathrm{a}}(1 \mathrm{H}, \mathrm{m})$ & 70.4 \\
\hline $6^{\prime}$ & $1.23(3 \mathrm{H}, \mathrm{d}, J=6.0 \mathrm{~Hz})$ & 18.1 \\
\hline \multicolumn{3}{|c|}{, } \\
\hline $1^{\prime \prime}$ & $4.61(1 \mathrm{H}, \mathrm{d}, J=7.5 \mathrm{~Hz})$ & 105.9 \\
\hline $2^{\prime \prime}$ & $3.35^{\mathrm{a}}(1 \mathrm{H}, \mathrm{m})$ & 72.3 \\
\hline $3^{\prime \prime}$ & $3.39^{\text {a }}(1 \mathrm{H}, \mathrm{m})$ & 77.7 \\
\hline $4^{\prime \prime}$ & $3.66^{\mathrm{a}}(1 \mathrm{H}, \mathrm{m})$ & 72.6 \\
\hline $5^{\prime \prime}$ & $3.37^{\text {a }}(1 \mathrm{H}, \mathrm{m})$ & 77.8 \\
\hline $6 " a$ & $3.74^{\mathrm{a}}(1 \mathrm{H}, \mathrm{dd}, J=11.9 ; 4.7 \mathrm{~Hz}, 1 \mathrm{H})$ & 62.0 \\
\hline $6 " b$ & $3.85^{\mathrm{a}}(1 \mathrm{H}, \mathrm{dd}, J=11.9 ; 2.31 \mathrm{~Hz}, 1 \mathrm{H})$ & \\
\hline
\end{tabular}

\subsection{Antioxidant Activity Potentials of Identified Compounds}

Table 3 shows the superoxide radical-scavenging activity, ORAC radical-scavenging activity, chelation of ferrous ions, and inhibition of NO activity of compounds 1-8 that were determined using ISP extraction technology for S. formosanum N.E.Br.

Compounds 1-3 are cyanogenic glycosides, Compounds 4-6 are flavonoid glycosides, and compounds $\mathbf{7}$ and $\mathbf{8}$ are other compounds. Compounds $\mathbf{4}$ and $\mathbf{5}$ are kaemferol glycosides, whereas compound 6 is a flavone glycoside. The radical-scavenging activity of these compounds was ranked as $7>6>5>4>2>8>1>3$ in the superoxide radical-scavenging activity assay; $6>5>4>8$ in the ORAC radical-scavenging activity assay; $6>5>4>7>8>2>3>1$ in the assay on the chelation of ferrous ions; and $5>6>4>8>7>1>2 \approx 3$ in the NO activity inhibition assay. Among these compounds, compounds 6 and 5 exhibited the highest antioxidant capability, as determined using the afore-mentioned methods (superoxide radical-scavenging activity: $1.03 \mathrm{vs} .0 .95 \mathrm{mmol}$ of TE; ORAC radical-scavenging activity: 1.06 vs. $1.03 \mathrm{mmol}$ of TE; chelation of ferrous ions: 1.23 vs. $1.14 \mathrm{mmol}$ of 
TE; and inhibition of NO activity: 0.83 vs. 1.01 mmole of TE, respectively). As mentioned previously, the structural characteristics of the analytes are mainly crucial to determining antioxidant capability.

Table 3. Antioxidant activities of pure compounds isolated from the isopropanol layer of Sedum formosanum N.E.Br. Values represent means $\pm \operatorname{SD}(n=3)$.

\begin{tabular}{|c|c|c|c|c|}
\hline Compounds & $\begin{array}{c}\text { FRAP } \\
(\mathrm{mol} \text { of } \mathrm{TE} / \mathrm{mol})^{a}\end{array}$ & $\begin{array}{c}\text { SOD } \\
(\mathrm{mol} \text { of } \mathrm{TE} / \mathrm{mol})^{a}\end{array}$ & $\begin{array}{l}\mathrm{NO}^{*} \text { Scavenging } \\
(\mathrm{mol} \text { of TE/ mol) }\end{array}$ & $\begin{array}{c}\text { ORAC } \\
\left(_{(\mathrm{mol} \mathrm{of} \mathrm{TE} / \mathrm{mol})^{a}}\right.\end{array}$ \\
\hline 1 & $0.17 \pm 0.01$ & $0.25 \pm 0.01$ & $0.09 \pm 0.04$ & $\mathrm{nt}^{\mathrm{c}}$ \\
\hline 2 & $0.33 \pm 0.02$ & $0.53 \pm 0.01$ & $\mathrm{nd}^{\mathrm{b}}$ & $\mathrm{nt}^{\mathrm{c}}$ \\
\hline 3 & $0.29 \pm 0.01$ & $0.19 \pm 0.01$ & $\mathrm{nd}^{\mathrm{b}}$ & $\mathrm{nt}^{\mathrm{c}}$ \\
\hline 4 & $0.91 \pm 0.04$ & $0.81 \pm 0.04$ & $0.59 \pm 0.02$ & $0.82 \pm 0.04$ \\
\hline 5 & $1.14 \pm 0.01$ & $0.95 \pm 0.03$ & $1.01 \pm 0.05$ & $1.03 \pm 0.03$ \\
\hline 6 & $1.23 \pm 0.01$ & $1.03 \pm 0.04$ & $0.83 \pm 0.02$ & $1.06 \pm 0.06$ \\
\hline 7 & $0.82 \pm 0.02$ & $1.21 \pm 0.07$ & $0.32 \pm 0.01$ & $\mathrm{nt}^{\mathrm{c}}$ \\
\hline 8 & $0.60 \pm 0.02$ & $0.51 \pm 0.07$ & $0.48 \pm 0.05$ & $0.64 \pm 0.02$ \\
\hline
\end{tabular}

Trolox (reference) $1.00 \pm 0.01$

$\mathrm{mol}$ of TE/mol a : are expressed as mole of Trolox equivalent per pure compound mole. Values represent means $\pm \mathrm{SD}(n=3)$. nd ${ }^{\mathrm{b}}$ : Not detected or lower than the calibration curve range. $\mathrm{nt}^{\mathrm{c}}$ : Not test in the antioxidant assay.

Compounds 4-6 contain similar aglycon structures (the C-ring 2,3-double bond does not link the $\mathrm{OH}$ in position 3 of compound 6), but at different positions and exhibit the conjugation of one or two sugar moieties. Thus, it is presumed that the solubility of these compounds [19], steric effects, and the degree of facilitation of the delocalization of electrons from the B-ring to the C-ring may determine their antioxidant capability [20]. Compounds 4 and 5 have identical structures (one sugar linked at the C3 position); however, compound 5 has one more sugar link at the A7 position. Compound $\mathbf{5}$ has improved solubility in an aqueous solution, facilitating the delocalization of the electrons from the B-ring to the C-ring. Consequently, compound 5 has higher antioxidant capability than compound 4 does. Although compounds 5 and $\mathbf{6}$ have equal numbers of sugars (linked at different positions of the aglycon structure), in compound 5, the one sugar link at the C3 position of the C-ring at the 2,3-double bond causes steric hindrance and may interrupt the delocalization of the electrons from the B-ring to the C-ring. Hence, compound $\mathbf{6}$ was more efficient than compound $\mathbf{5}$ in the antioxidant capability assays, except for $\mathrm{NO}$ inhibiting activity. Compound $\mathbf{5}$ is traditionally used for treating kidney diseases among Mexican natives and has been isolated and identified from certain ferns [21,22].

The linking of cyanide at different positions of the double bond may cause differences in antioxidant capability among compounds 1-3. Cyanogenic glycosides has little toxicity and are crucial compounds for pharmaceutical use. Compound $\mathbf{1}$ is the main natural medicine constituent of R. quadrifida (Pall.) Fisch. et Mey which inhibits histamine release with anti-2,4-dinitrophenyl IgE from sensitized rat peritoneal exudate cells, and exhibits antiallergic activity in rats, according to a passive cutaneous anaphylaxis test [23]. Compound 3 is the main active constituent of S. sarmentosum and is used to treat chronic viral hepatitis in Asia [15].

Compound $\mathbf{8}$ is a $p$-coumaric acid derivative, and compound $\mathbf{7}$ is a $p$-hydroxybenzyl alcohol derivative. The antioxidant capability of compound $\mathbf{7}$ is higher than that of compound $\mathbf{8}$, except for inhibition of $\mathrm{NO}$ activity. Compound $\mathbf{7}$ is the main active constituent of Rhizoma gastrodiae, and is considered a traditional Chinese medicine proven to be an effective and safe drug for clinical use to prevent neurocognitive decline following cardiopulmonary bypass, and benefitting older refractory hypertension patients [24]. This compound can improve the association between endothelin and NO in plasma [25]. 
2.4. Comparison of the Chromatograms after Isopropanol Salting-Out Pretreatment and n-Butanol Partition Extraction Technology Using HPLC Separation

Figure 3 a reveals that the retention times $\left(t_{R}, \min \right)$ of compounds 5 and $\mathbf{6}$, which exhibited the highest antioxidant activity in all of the antioxidant assays, were 19.0 and $20.0 \mathrm{~min}$, respectively. The HPLC chromatograms of the separation of the compounds that were obtained using the ISP and BP extraction technology differ widely (Figure 3b,c). The ISP extraction technology is suitable for obtaining compounds 5 and $\mathbf{6}$. This indicates that the antioxidant capability, achieved using ISP extraction technology was 1.38-3.65 times higher than that achieved using BP extraction technology.
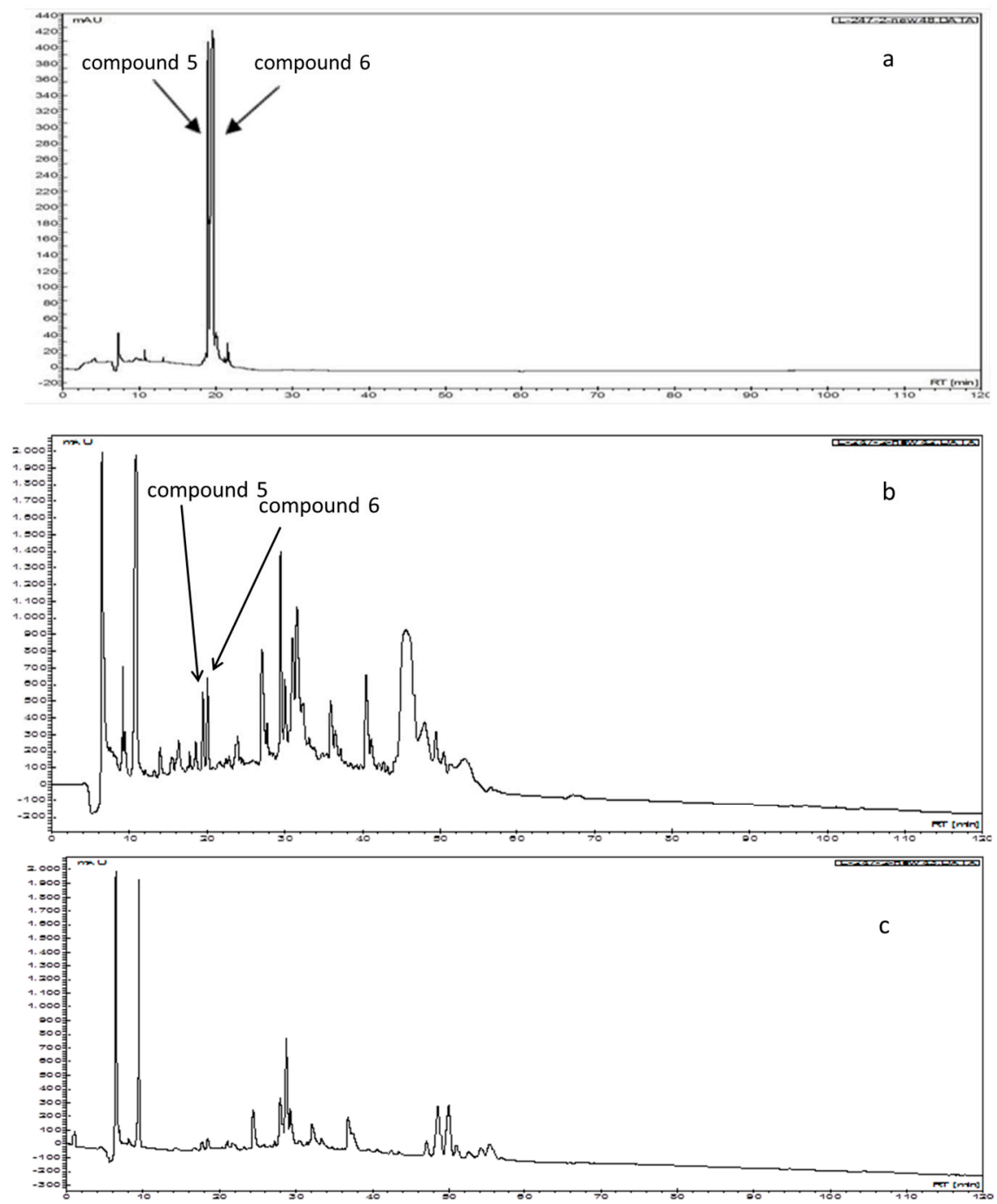

Figure 3. Analytical HPLC chromatogram monitored using $\lambda_{210}$ UV absorption: (a) compounds 5 and 6; (b) isopropanol salting-out extracts of S. formosanum N.E.Br; (c) $n$-butanol partition extracts of Sedum formosanum N.E.Br.

\section{Materials and Methods}

\subsection{General Procedures}

Through the extraction and isolation of solvents, analytical reagents of various grades, including isopropanol, dichloromethane, methanol, and n-butanol, were obtained from ECHO (Miaoli, Taiwan). HPLC grade acetonitrile (ACN) was purchased from Merck Chemicals (Darmstadt, Germany). $\mathrm{KH}_{2} \mathrm{PO}_{4}, \mathrm{~K}_{2} \mathrm{HPO}_{4}$, phosphate-buffered saline, and the NMR solvents, methanol- $d_{4}, \mathrm{DMSO}-d_{6}$, 
nitroblue tetrazolium (NBT), nicotinamide adenine dinucleotide (NADH), phenazine methosulfate (PMS), ferrous chloride, ferrozine, sodium nitroprusside (SNP), 2,2-azobis(2-amidopropane) dihydrochloride (AAPH), sulfanilamide, and napthyethylenediamine dihydrochloride (NED), were obtained from Sigma-Aldrich Chemical Co. (St. Louis, MO, USA). Trolox and fluorescein disodium were obtained from Aldrich (Milwaukee, WI, USA). Ultra-pure water $(>18 \mathrm{M} \Omega$ ) was obtained using a SG-Ultra water purification system (SG Water USA, LLC, USA), degassed under vacuum, and filtered through a $0.45 \mu \mathrm{m}$ membrane filter before use. Sodium chloride was purchased from Union Chemical Works Ltd. (Hsinchu, Taiwan).

IR spectra were obtained using a Spectrum 100 FT-IR spectrometer (Perkin-Elmer, Wellesley, MA, USA). UV spectra were obtained using a U-300 spectrophotometer (Perkin-Elmer) with spectroscopy-grade methanol (Merck). ${ }^{1} \mathrm{H}-\mathrm{NMR}$ and ${ }^{13} \mathrm{C}-\mathrm{NMR}$ spectra were measured using a Innova 400 spectrometer (Varian, Palo Alto, CA, USA). The chemical shift values of the ${ }^{1} \mathrm{H}$ - and ${ }^{13} \mathrm{C}-\mathrm{NMR}$ spectra are presented as $\delta(\mathrm{ppm})$ with TMS as the internal standard. ESI-MS data were recorded on a LCQ instrument (Thermo-Finnigan, San Jose, CA, USA), and HR-FT-MS data were measured using a JMS-SX/SX 102A tandem mass spectrometer (JEOL Ltd., Tokyo, Japan). HPLC data were obtained using the Varian ProStar 240 Solvent Delivery Module.

Silica gel 60 (Merck 70-230 mesh, 230-400 mesh, ASTM) and Sephadex-LH-20 (Pharmacia, Uppsala, Sweden) were used in column chromatography. The radical-scavenging activity assays were performed using an ELISA reader.

\subsection{Sources of Sedum formosanum}

Taichung Veterans General Hospital in Taichung, Taiwan, provided the S. formosanum N.E.Br. samples. These samples were dried in an oven at $40^{\circ} \mathrm{C}$ and stored overnight before extraction.

\subsection{Determination of the Two Types of Extraction Technology}

\subsubsection{Isopropanol Salting-Out Pretreatment Extraction Technology}

The S. formosanum N.E.Br. powder $(1 \mathrm{~g})$ in aqueous $60 \%$ methanol $(10 \mathrm{~mL})$ was sonicated for 1 $\mathrm{h}$ at room temperature. Filter paper (Toyo Roshi Kaisha, Ltd., Tokyo, Japan) was used to filter the solution, which was then poured into a $50-\mathrm{mL}$ round-bottomed flask. The residues were extracted twice by using $10 \mathrm{~mL}$ of aqueous $60 \%$ methanol $(2 \times 10 \mathrm{~mL})$. Under reduced pressure, the extract was evaporated, the methanol was removed, and water was added to yield a $50 \mathrm{~mL}$ aqueous solution. Subsequently, isopropanol $(50 \mathrm{~mL})$ and $\mathrm{NaCl}(12 \mathrm{~g})$ were added to this aqueous solution, and this solution was separated to yield the isopropanol fraction. Under reduced pressure and at a temperature of $40{ }^{\circ} \mathrm{C}$, this fraction was evaporated to yield a dry residue [26,27]. Using water, this residue was dissolved to prepare a working solution $(1000 \mathrm{mg} / \mathrm{mL})$ for determining the antioxidant capability.

\subsection{2. $n$-Butanol Partition Extraction Technology}

The S. formosanum N.E.Br. powder $(1 \mathrm{~g})$ in aqueous $60 \%$ methanol $(10 \mathrm{~mL})$ was sonicated for 1 $\mathrm{h}$ at room temperature. Using filter paper (Toyo Roshi Kaisha, Ltd.), the solution was filtered and then poured into a 50-mL round-bottomed flask. The residues were extracted twice by using aqueous $60 \%$ methanol $(2 \times 10 \mathrm{~mL})$. Under reduced pressure, the extract was evaporated, the methanol was removed, and water was added to yield a $50 \mathrm{~mL}$ aqueous solution. Next, $n$-butanol ( $50 \mathrm{~mL}$ ) was added to this aqueous solution to yield the $n$-butanol fraction. Under reduced pressure and at a temperature of $40{ }^{\circ} \mathrm{C}$, the $n$-butanol fraction was evaporated to yield a dry residue. This residue was dissolved in water, and a working solution $(1000 \mathrm{mg} / \mathrm{mL})$ was prepared to determine the antioxidant capability.

\subsection{Extraction and Purification}

The S. formosanum N.E.Br. powder ( $238 \mathrm{~g}$ ) was extracted four-times at room temperature for $24 \mathrm{~h}$ using aqueous $60 \%$ methanol $(400 \mathrm{~mL})$. The extract was filtered, the methanol was removed through 
reduced pressure evaporation, and water was added to obtain a $1 \mathrm{~L}$ aqueous solution. An aliquot $(200 \mathrm{~mL})$ of the aqueous solution, isopropanol $(200 \mathrm{~mL})$ and sodium chloride $(40 \mathrm{~g})$ were added, and the solution was then separated to obtain isopropanol layers and aqueous layers. The isopropanol layers were collected, and a crude extract $(33.6 \mathrm{~g})$ was yielded through reduced pressure evaporation. The isopropanol extract (33.6 g) was chromatographed on silica gel and eluted using a gradient of $\mathrm{CH}_{2} \mathrm{Cl}_{2}-\mathrm{CH}_{3} \mathrm{OH}-\mathrm{H}_{2} \mathrm{O}$ (from 89:10:1 to 59:40:1) to yield three fractions. The antioxidant capability of fractions 2 and 3 was higher than that of fraction 1, as determined using antioxidant assays (data not show).

Fraction 2 was chromatographed using a Sephadex-LH-20 column and eluted using a $\mathrm{H}_{2} \mathrm{O}-\mathrm{CH}_{3} \mathrm{OH}$ gradient (from 100:0 to 0:100) to obtain two fractions. Fraction 1 was purified using semi-preparative HPLC with $\mathrm{H}_{2} \mathrm{O}$ and ACN as an eluted solvent at a flow rate of $2 \mathrm{~mL} / \mathrm{min}$ to obtain rhodiocyanoside A (1, 3.6 mg), rhodiocyanoside D (2, 3.0 mg), sarmentosin (3, $10.0 \mathrm{mg})$. Fraction 2 was purified using semi-preparative HPLC with $\mathrm{H}_{2} \mathrm{O}$ and $A C N$ as an eluted solvent at a flow rate of $2 \mathrm{~mL} / \mathrm{min}$ to yield gastrodin $(7,1.0 \mathrm{mg})$, kaempferol-3-O- $\beta$-D-glucopyranoside $(4,3.4 \mathrm{mg})$, and cis- $p$-coumaric acid-4- $\beta$-O-L-glucopyranosyl- $(1 \rightarrow 3)$ - $\alpha$-L-rahmnopyranoside methyl ester $(8,2.7 \mathrm{mg})$.

Fraction 3 was chromatographed using a Sephadex-LH-20 column and eluted using a $\mathrm{H}_{2} \mathrm{O}-\mathrm{CH}_{3} \mathrm{OH}$ gradient (from 100:0 to 0:100) to obtain four fractions. Fraction 2 was purified using semi-preparative HPLC with $\mathrm{H}_{2} \mathrm{O}$ and $\mathrm{ACN}$ as an eluted solvent at a flow rate of $2 \mathrm{~mL} / \mathrm{min}$ to obtain kaempferol-3,7-di-O- $\beta$-D-glucopyranoside $(5,3.1 \mathrm{mg})$ and vicenin-2 (6) $(5.2 \mathrm{mg})$. Figure 4 is a flow chart that displays the isolation and analytical sequences. To examine the antioxidant capability of the compounds, methanol of each compound was dissolved to prepare a work solution $(1000 \mathrm{mg} / \mathrm{mL})$.

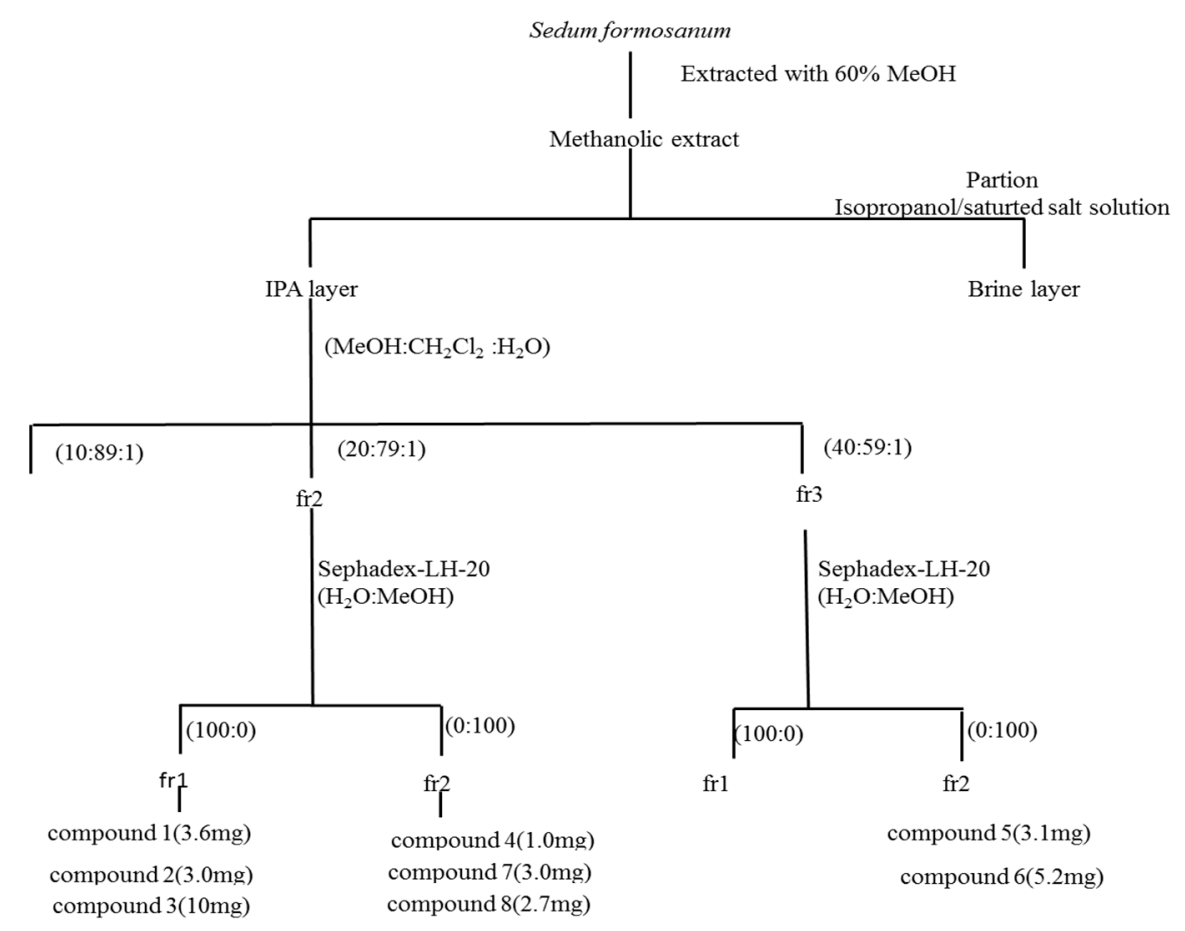

Figure 4. A flow chart the isolation and analytical sequences.

\subsection{Compound Characterization}

Compound 1: $\mathrm{C}_{11} \mathrm{H}_{16} \mathrm{NO}_{6}$, white powder, UV $\lambda_{\max }^{\mathrm{MeOH}} \mathrm{nm}$ : 208. ESI-MS: $282[\mathrm{M}+\mathrm{Na}]^{+}, \mathrm{IR} v_{\max } \mathrm{cm}^{-1}$ : 3410, 2222, 1655, and 1076. ${ }^{1} \mathrm{H}-\mathrm{NMR}\left(\right.$ methanol- $\left._{4}\right): 6.46(1 \mathrm{H}, \mathrm{qt}, J=1.2,6.4 \mathrm{~Hz}, \mathrm{H}-3), 4.42(1 \mathrm{H}, \mathrm{ddq}$, $J=1.2,6.4,13.6 \mathrm{~Hz}, \mathrm{H}-4 \mathrm{a}), 4.54(1 \mathrm{H}, \mathrm{ddq}, J=1.2,6.4,13.6 \mathrm{~Hz}, \mathrm{H}-4 \mathrm{~b}), 1.98(1 \mathrm{H}, J=1.2 \mathrm{~Hz}, \mathrm{H}-5)$, $\beta$-D-glucopyranosyl moiety: $4.29\left(1 \mathrm{H}, J=7.6 \mathrm{~Hz}, \mathrm{H}-1^{\prime}\right), 3.18 \sim 3.37$ (m, glucose proton overlapped by water proton), $3.67\left(1 \mathrm{H}, \mathrm{dd}, J=5.6,12.6 \mathrm{~Hz}, \mathrm{H}-66^{\prime} \mathrm{a}\right), 3.86\left(1 \mathrm{H}, \mathrm{dd}, J=1.2,12.6 \mathrm{~Hz}, \mathrm{H}-6{ }^{\prime} \mathrm{b}\right) .{ }^{13} \mathrm{C}-\mathrm{NMR}$ 
(methanol- $\left.d_{4}\right): 118.1,112.6,147.0,71.4,71.4,20.2, \beta$-D-glucopyranosyl moiety: 104.0, 75.0, 78.0, 78.0, 71.4, 62.6, ppm. Moreover, the ${ }^{1} \mathrm{H}-\mathrm{NMR}$ and ${ }^{13} \mathrm{C}-\mathrm{NMR}$ data of compound 1 are consistent with existing literature [12]. Therefore, on the basis of these data, compound $\mathbf{1}$ was determined as rhodiocyanoside A.

Compound 2: $\mathrm{C}_{11} \mathrm{H}_{16} \mathrm{NO}_{6}$, white powder, UV $\lambda_{\max }^{\mathrm{MeOH}} \mathrm{nm}: 211$. ESI-MS: $282[\mathrm{M}+\mathrm{Na}]^{+}, 725[\mathrm{M}-\mathrm{H}]^{-}$,

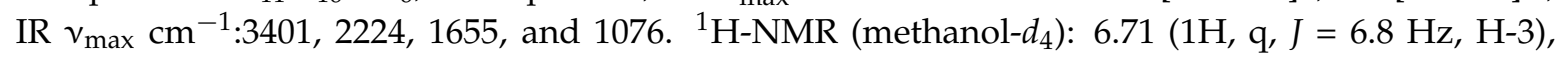
$4.24(1 \mathrm{H}, \mathrm{ddq}, J=1.2,6.4,13.6 \mathrm{~Hz}, \mathrm{H}-4 \mathrm{a}), 4.41(1 \mathrm{H}, \mathrm{ddq}, J=1.2,6.4,13.6 \mathrm{~Hz}, \mathrm{H}-4 \mathrm{~b}), 2.01(1 \mathrm{H}, \mathrm{d}$, $J=6.8 \mathrm{~Hz}, \mathrm{H}-5), \beta$-D-glucopyranosyl moiety: $4.29\left(1 \mathrm{H}, \mathrm{d}, J=7.6 \mathrm{~Hz}, \mathrm{H}-1^{\prime}\right), 3.20 \sim 3.37$ (m, glucose proton overlapped by water proton), $3.67(1 \mathrm{H}, \mathrm{dd}, J=5.6,12.0 \mathrm{~Hz}, \mathrm{H}-6$ 'a), 3.86 (1H, dd, J =1.6, 12.0 Hz, H-6'b). ${ }^{13}$ C-NMR (methanol- $d_{4}$ ): 117.4, 114.0, 148.1, 71.4, 71.4, 20.2, $\beta$-D-glucopyranosyl moiety: 103.2, 74.9, 78.0, 78.0, 71.5, 62.7 ppm. Moreover, the ${ }^{1} \mathrm{H}-\mathrm{NMR}$ and ${ }^{13} \mathrm{C}-\mathrm{NMR}$ data of compound 2 are consistent with existing literature [23]. Therefore, on the basis of these data, compound 2 was determined as rhodiocyanoside D.

Compound 3: $\mathrm{C}_{11} \mathrm{H}_{17} \mathrm{NO}_{7}$, colorless gum, UV $\lambda_{\max }^{\mathrm{MeOH}} \mathrm{nm}$ : 212. ESI-MS: $298[\mathrm{M}+\mathrm{Na}]^{+}$, IR $v_{\max } \mathrm{cm}^{-1}$ : 3540 3240, 2235, 1607, and 1640. ${ }^{1} \mathrm{H}-\mathrm{NMR}$ (methanol- $\left.d_{4}\right): 6.67(1 \mathrm{H}, \mathrm{tt}, J=1.6,6.4 \mathrm{~Hz}, \mathrm{H}-3), 4.49(1 \mathrm{H}$, ddq, $J=1.2,6.4,13.6 \mathrm{~Hz}, \mathrm{H}-4 \mathrm{a}), 4.60$ (ddt, $J=1.2,6.4,13.6 \mathrm{~Hz}, \mathrm{H}-4 \mathrm{~b}), 4.15$ (1H, q, $J=1.2 \mathrm{~Hz}, \mathrm{H}-5$ ), $\beta$-D-gluco-pyranosyl moiety: $4.32\left(1 \mathrm{H}, \mathrm{d}, J=8.0 \mathrm{~Hz}, \mathrm{H}-1^{\prime}\right), 3.20 \sim 3.37$ (m, glucose proton overlapped by water proton), $3.67\left(1 \mathrm{H}, \mathrm{dd}, J=5.6,12.0 \mathrm{~Hz}, \mathrm{H}-6\right.$ 'a), $3.86\left(1 \mathrm{H}, \mathrm{dd}, J=1.2,12.0 \mathrm{~Hz}, \mathrm{H}-6{ }^{\prime} \mathrm{b}\right) .{ }^{13} \mathrm{C}-\mathrm{NMR}$ (methanol- $d_{4}$ ): 118.1, 116.8, 144.7, 68.5, 68.5, 63.2, $\beta$-D-glucopyranosyl moiety: 104.2, 75, 78.0, 78.0, 71.4, $62.6 \mathrm{ppm}$. Moreover, the ${ }^{1} \mathrm{H}-\mathrm{NMR}$ and ${ }^{13} \mathrm{C}-\mathrm{NMR}$ data of compound 3 are consistent with existing literature [28]. Therefore, on the basis of these data, compound 3 was determined as sarmentosin.

Compound 4: $\mathrm{C}_{21} \mathrm{H}_{20} \mathrm{O}_{11}$, yellowish amorphous powder, $\mathrm{UV} \lambda_{\max }^{\mathrm{MeOH}} \mathrm{nm}: 270,355$. ESI-MS:

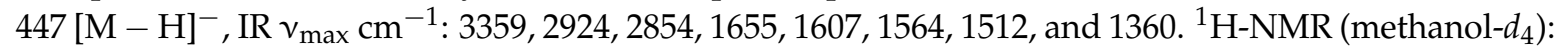
$6.03(1 \mathrm{H}, \mathrm{d}, J=1.87 \mathrm{~Hz}, \mathrm{H}-6), 6.18(1 \mathrm{H}, \mathrm{d}, J=1.87 \mathrm{~Hz}, \mathrm{H}-8), 8.03\left(2 \mathrm{H}, \mathrm{d}, J=8.96 \mathrm{~Hz}, \mathrm{H}-2^{\prime}, 6^{\prime}\right), 6.84$ $\left(2 \mathrm{H}, \mathrm{d}, J=8.96 \mathrm{~Hz}, \mathrm{H}-3^{\prime}, 5^{\prime}\right)$, $\beta$-D-glucopyranosyl moiety: $5.08(1 \mathrm{H}, \mathrm{d}, J=7.50 \mathrm{~Hz} 3.18-3.63(\mathrm{~m}$, glucose proton overlapped by water proton). ${ }^{13} \mathrm{C}-\mathrm{NMR}$ (methanol- $d_{4}$ ): $159.4,133.5,179.9,161.4,102.6$, 163.3, 95.1, 156.6, 106.2, 121.2, 130.8, 114.6, 160.8, 114.6, 130.8, $\beta$-D-glucopyranosyl moiety: 98.7, 73.9, 77.3, 72.4, 78.0, $62.0 \mathrm{ppm}$. Moreover, the ${ }^{1} \mathrm{H}-\mathrm{NMR}$ and ${ }^{13} \mathrm{C}-\mathrm{NMR}$ data of compound 4 are consistent with existing literature [29]. Therefore, on the basis of these data, compound 4 was elucidated to be kaempferol-3-O- $\beta$-D-glucopyranoside.

Compound 5: $\mathrm{C}_{27} \mathrm{H}_{30} \mathrm{O}_{16}$, faint yellow powder, UV $\lambda_{\max }^{\mathrm{MeOH}} \mathrm{nm}: 277,346$. ESI-MS: 609 [M - H] ${ }^{-}, \mathrm{IR}$ $v_{\max } \mathrm{cm}^{-1}: 3385,1657,1602,1589,1545,1492,1415,1347,1307,1283$, and 1186. ${ }^{1} \mathrm{H}-\mathrm{NMR}\left(\mathrm{methanol}^{-} d_{4}\right)$ : $6.43(1 \mathrm{H}, \mathrm{d}, J=2.07 \mathrm{~Hz}, \mathrm{H}-6), 6.78(1 \mathrm{H}, \mathrm{d}, J=2.07 \mathrm{~Hz}, \mathrm{H}-8), 8.05\left(2 \mathrm{H}, \mathrm{d}, J=9.0 \mathrm{~Hz}, \mathrm{H}-2^{\prime}, 6^{\prime}\right), 6.88$ $\left(2 \mathrm{H}, \mathrm{d}, J=9.0 \mathrm{~Hz}, \mathrm{H}-3^{\prime}, 5^{\prime}\right)$; $\beta$-D-glucopyranosyl moiety: $5.47\left(1 \mathrm{H}, \mathrm{d}, J=7.35 \mathrm{~Hz}, \mathrm{H}-1^{\prime \prime}\right), 3.15 \sim 3.75$ (m); $5.07\left(1 \mathrm{H}, \mathrm{d}, J=7.36 \mathrm{~Hz}, \mathrm{H}-1^{\prime \prime \prime}\right), 3.15 \sim 3.75$ (m, glucose proton overlapped by water proton). ${ }^{13}$ C-NMR (methanol- $d_{4}$ ): 157, 134, 178.1, 161.4, 99.9, 163.3, 95.1, 156.6, 106.2 121.2, 131.6, 115.8, 160.8, 115.8, 131.6; $\beta$-D-glucopyranosyl moiety: 100.25, 74.7, 76.1, 72.4, 75.7, 62.4; 99.9, 74.7, 75.4, 72.2, 75.4, $62.2 \mathrm{ppm}$. Moreover, the ${ }^{1} \mathrm{H}-\mathrm{NMR}$ and ${ }^{13} \mathrm{C}-\mathrm{NMR}$ data of compound 5 are consistent with existing literature [30]. Therefore, on the basis of these data, compound 5 was elucidated to be kaempferol-3,7-di-O- $\beta$-D-glucopyranoside.

Compound 6: $\mathrm{C}_{27} \mathrm{H}_{30} \mathrm{O}_{15}$, yellow amorphous powder $\mathrm{UV} \lambda_{\max }^{\mathrm{MeOH}} \mathrm{nm}: 270,329$. ESI-MS: 593 [M - H] ${ }^{-}$, IR $v_{\max } \mathrm{cm}^{-1}: 3395,2972,2850,1652,1629,1582,1443,1362,1286,1221$, and 1181. ${ }^{1} \mathrm{H}-\mathrm{NMR}$ $\left(\right.$ methanol-d $\left.d_{4}\right): 6.59(1 \mathrm{H}, \mathrm{s}, \mathrm{H}-3), 7.94\left(2 \mathrm{H}, \mathrm{d}, J=8.1 \mathrm{~Hz}, \mathrm{H}-2^{\prime}, 6^{\prime}\right), 6.91\left(2 \mathrm{H}, \mathrm{d}, J=8.0 \mathrm{~Hz}, \mathrm{H}-3^{\prime}\right.$, 5'); $\beta$-D-glucopyranosyl moiety: $5.01\left(1 \mathrm{H}, \mathrm{d}, J=10.8 \mathrm{~Hz}, \mathrm{H}-1^{\prime \prime}\right), 3.5-4.1(\mathrm{~m}) ; 5.04(1 \mathrm{H}, \mathrm{d}, J=10.8 \mathrm{~Hz}$, H-1"'), 3.5-4.1 m (m, glucose proton overlapped by water proton). ${ }^{13} \mathrm{C}-\mathrm{NMR}$ (methanol- $\left.d_{4}\right): 166.83$, 103.89, 184.37, 160.7, 108.2, 161.87, 106.2, 157.65, 105.64, 123.51, 130.3, 117.22, 162.98, 117.22, 130.3; $\beta$-D-glucopyranosyl moiety: 75.2, 75.7, 82.8, 72.4, 80.1, 71; 76.4, 75.4, 82.5, 72.2, 79.3, 71 ppm. Moreover, 
the ${ }^{1} \mathrm{H}-\mathrm{NMR}$ and ${ }^{13} \mathrm{C}-\mathrm{NMR}$ data of compound 6 are consistent with existing literature [31]. Therefore, on the basis of these data, compound 6 was identified as vicenin- 2 .

Compound 7: $\mathrm{C}_{13} \mathrm{H}_{18} \mathrm{O}_{7}$, colorless needles, $\mathrm{UV} \lambda_{\max }^{\mathrm{MeOH}} \mathrm{nm}: 223$, 273. ESI-MS: 309 [M + Na] $]^{+}, \mathrm{IR} v_{\max }$ $\mathrm{cm}^{-1}: 3500 \sim 3200,1615,1590$, and 1575. ${ }^{1} \mathrm{H}-\mathrm{NMR}$ (methanol- $\left.d_{4}\right): 7.26(1 \mathrm{H}, \mathrm{d}, J=8.4 \mathrm{~Hz}, \mathrm{H}-2,6), 7.06$ $(1 \mathrm{H}, \mathrm{d}, J=8.4 \mathrm{~Hz}, \mathrm{H}-3,5), 4.53$ (2H, s, H-7); $\beta$-D-glucopyranosyl moiety: $4.66\left(1 \mathrm{H}, J=7.8 \mathrm{~Hz}, \mathrm{H}-1^{\prime}\right)$, 3.33-3.49 (m, glucose proton overlapped by water proton), $3.69(1 \mathrm{H}, \mathrm{dd}, J=5.2,12.0 \mathrm{~Hz}, \mathrm{H}-6 \mathrm{a}$ ) , 3.87 $\left(1 \mathrm{H}, \mathrm{dd}, J=2.0,12.0 \mathrm{~Hz}, \mathrm{H}-6{ }^{\prime} \mathrm{b}\right) .{ }^{13} \mathrm{C}-\mathrm{NMR}$ (methanol- $\left.d_{4}\right): 136.6,130.9,118.2,159.2,118.2,130.9,65.5$, $104.2,74.9,78.0,71.3,77.9,62.5,62.5 \mathrm{ppm}$. Moreover, the ${ }^{1} \mathrm{H}-\mathrm{NMR}$ and ${ }^{13} \mathrm{C}-\mathrm{NMR}$ data of compound 7 are consistent with existing literature [32]. Therefore, on the basis of these data, compound 7 was determined as gastrodin.

Compound 8: White powder, HR-FT-MS $[\mathrm{M}+\mathrm{H}]^{+} m / z: 487.1812$ (calculated at 486.47), $\mathrm{UV} \lambda_{\max }^{\mathrm{MeOH}} \mathrm{nm}$ : 277, 346, IR $v_{\max } \mathrm{cm}^{-1}: 3362,2953,2843,1660,1462,1420,1123$, and 1016. Table 2 lists the ${ }^{1} \mathrm{H}-\mathrm{NMR}$ and ${ }^{13} \mathrm{C}-\mathrm{NMR}$ data.

\subsection{Measurement of Antioxidant Activity}

\subsubsection{Superoxide Radical Scavenging Activity Assay}

Using the method of Lee et al., the superoxide anion scavenging activity of the sample was measured [33]. Through NADH oxidation in a non-enzymatic PMS/NADH system, superoxide anions were generated and assayed through the reduction of NBT. The reagents were prepared in a $100 \mathrm{mM}$ phosphate buffer ( $\mathrm{pH} 7.4)$. The reaction mixture contained $10 \mu \mathrm{L}$ of the test sample (1000 ppm), $100 \mu \mathrm{L}$ of NBT $(100 \mu \mathrm{M})$, and $100 \mu \mathrm{L}$ of NADH $(468 \mu \mathrm{M})$. To this reaction mixture, $10 \mu \mathrm{L}$ of PMS $(60 \mu \mathrm{M})$ was added, and the mixture was incubated at room temperature for $15 \mathrm{~min}$. The peak of the UV spectrophotometer changed at $560 \mathrm{~nm}$ and recorded the color reaction between the superoxide anion radical and NBT. Trolox was used as a standard for comparative analysis. The reaction mixture without the test sample and without PMS was used as the control and a blank, respectively. Various concentrations of the Trolox solution $(20,80,121,181,222$, and $242 \mu \mathrm{M})$ were used for plotting a calibration curve. The assay results were expressed as the mean moles of TE per moles of the compounds $\pm \mathrm{SD}$, and all analyses were performed in triplicate:

$$
\text { Scavenging activity }(\%)=\left[1-\left(\mathrm{Abs}_{\text {sample }}\right) /\left(\mathrm{Abs}_{\text {control }}\right)\right] \times 100
$$

\subsubsection{Oxygen Radical Absorbance Capacity Assay}

The peroxyl radical scavenging efficacy of the samples was measured using the ORAC assay [34]. A stock solution and dilutions of the test samples were prepared in potassium phosphate solution buffer $(75 \mathrm{mmol} / \mathrm{L}), \mathrm{pH}$ 7.4. Trolox and AAPH were adopted as the standard and peroxyl generator, respectively. Each fluorescein solution $(150 \mu \mathrm{L})(40 \mathrm{nM}), 25 \mu \mathrm{L}$ of AAPH $(153 \mathrm{mM})$, and $25 \mu \mathrm{L}$ of the sample $(1000 \mathrm{ppm})$ were well mixed. The temperature of the incubator was set at $37^{\circ} \mathrm{C}$ for $30 \mathrm{~min}$ before measurement, and the fluorescence reading time was recorded every $2 \mathrm{~min}$ for $2 \mathrm{~h}$. A fluorescence microplate reader was implemented using an excitation wavelength of $485 \mathrm{~nm}$ and an emission wavelength of $528 \mathrm{~nm}$. The areas of the samples under the time and fluorescence intensity were determined by subtracting the area of the blank, and these areas were then compared with those of the standard curve $(20,40,60,80,100,150$, and $220 \mu \mathrm{M})$. The assay results were expressed as the mean moles of TE per moles of the compounds $\pm \mathrm{SD}$, and all the analyses were performed in triplicate.

\subsubsection{Assay on Chelation of Ferrous Ions}

The chelation of the ferrous ions of the sample was estimated using the method of Lim et al. [35]. The tested sample solutions $(10 \mu \mathrm{L})$ were added to a solution of $2.0 \mathrm{mM}$ ferrous chloride $(10 \mu \mathrm{L})$ and 
methanol $(370 \mu \mathrm{L})$. The reaction was initiated by adding $5 \mathrm{mM}$ ferrozine $(20 \mu \mathrm{L})$, and this mixture was then vigorously shaken and maintained at room temperature for $10 \mathrm{~min}$. The absorbance of the resulting solution was recorded at $562 \mathrm{~nm}$. Various concentrations of the Trolox solution $(12.5,50,100$, 125,175 , and $220 \mu \mathrm{M}$ ) were used for plotting a calibration curve. The assay results were expressed as the mean moles of TE per moles of the compounds \pm SD, and all the analyses were performed in triplicate.

$$
\text { Ferrous ion }- \text { chelating ability }(\%)=\left[1-\left(\mathrm{Abs}_{\text {sample }}\right) /\left(\mathrm{Abs}_{\text {control }}\right)\right] \times 100
$$

\subsubsection{Assay on Inhibition of Nitric Oxide Radical}

NO generated from aqueous SNP at physiological $\mathrm{pH}$ interacted with oxygen to produce nitrite ions, which were measured according to the Griess reaction [36]. NO scavengers compete with oxygen, possibly reducing the production of NO [37]. Aqueous SNP ( $5 \mathrm{mM}$, approximately $200 \mu \mathrm{L})$ and $0.2 \mathrm{M}$ potassium phosphate buffer ( $\mathrm{pH} 7.4,200 \mu \mathrm{L})$ were added to the test sample $(1000 \mathrm{ppm}, 200 \mu \mathrm{L})$. After incubation for $150 \mathrm{~min}$ at $25^{\circ} \mathrm{C}$, sulfanilamide $(15[w / v], 200 \mu \mathrm{L})$ was added to the incubated solution $(600 \mu \mathrm{L})$ and allowed to stand for $10 \mathrm{~min}$. Subsequently, NED $(0.1 \%$ [ $w / v], 200 \mu \mathrm{L})$ was added, and the mixture was incubated for $20 \mathrm{~min}$ at $25{ }^{\circ} \mathrm{C}$. The absorbance of chromophores was recorded at $546 \mathrm{~nm}$ against a blank sample. Various concentrations of the Trolox solution $(12.5,37.5,50.0,62.5$, and $75.0 \mu \mathrm{M}$ ) were used for preparing a calibration curve. The assay results were expressed as the mean moles of TE per moles of the compounds \pm SD, and all the analyses were performed in triplicate.

$$
\text { Nitric oxide radical scavenging }(\%)=\left[1-\left(\mathrm{Abs}_{\text {sample }}\right) /\left(\mathrm{Abs}_{\mathrm{control}}\right)\right] \times 100
$$

\subsection{Comparison of Chromatograms after Isopropanol Salting-Out Pretreatment and n-Butanol Partition Extractions Using HPLC Separation}

An appropriate volume of methanol was used to individually dissolve compounds 5 and $\mathbf{6}$ to prepare $1000 \mu \mathrm{g} / \mathrm{mL}$ stock solutions. The mixture of each stock solution $(100 \mu \mathrm{L})$ was used to prepare a standard working solution that contained $500 \mu \mathrm{g} / \mathrm{mL}$ of each compound. Reversed-phase chromatography was performed on compounds 5 and 6 (Merck C18 column [LiChriCART 5 Mm 250-4 RPC18e] and on a Phenomenex C18 guard column [AJ0-4287 $4.0 \times 3.0])$. The crude extracts were separated under the following experimental conditions: eluent flow rate of $0.4 \mathrm{~mL} / \mathrm{min}$; injection volume of $20 \mu \mathrm{L}$; detection wavelength of $210 \mathrm{~nm}$; ambient temperature; and an eluent of water (A) and ACN (B) mixtures. Using a linear gradient, the elution program was optimized as follows: $0 \mathrm{~min}, 0 \% \mathrm{~B} ; 120 \mathrm{~min}, 100 \% \mathrm{~B} ; 125 \mathrm{~min}, 100 \% \mathrm{~B}$; and $135 \mathrm{~min}, 0 \% \mathrm{~B}$. The retention times $\left(t_{R}, \mathrm{~min}\right)$ of compounds 5 and 6 were 19.0 and $20.0 \mathrm{~min}$, respectively. An appropriate volume of methanol was used to individually dissolve the crude extracts of ISP and BP extraction to obtain $1000 \mu \mathrm{g} / \mathrm{mL}$ work solutions. Chromatograms of these individual work solutions were obtained under identical experimental conditions for HPLC.

\subsection{Statistical Analysis}

Values are represented as the mean \pm SD of three parallel experiments and were analyzed through a $t$-test and analysis of variance.

\section{Conclusions}

This investigation demonstrated that the antioxidant capability of compounds obtained through ISP extraction was 1.38-3.65 times higher than that of compounds obtained through BP extraction in antioxidant assays. Eight compounds, namely three flavonoid glycosides, three cyanogenic glycosides, and two phenolic compounds, were extracted and isolated from S. formosanum N.E.Br. through the ISP method. Compound 8 is a new compound. Except for the inhibition of NO activity, the antioxidant capability of compound 6 was 1.03-1.23 times higher than that of the standard compound (Trolox). 
According to the HPLC chromatograms, ISP extraction had the highest efficiency to extract compounds 5 and 6. Furthermore, hydrophilic ISP extraction technology is superior to BP extraction technology regarding antioxidant capability and cost and reduces the risk to human health and the environment. Therefore, ISP extraction technology must replace BP extraction technology for extracting and isolating higher polar compounds of natural products. This study devised an effective method of extracting and identifying active compounds for S. formosanum N.E.Br. that can be used as nutraceuticals and pharmaceuticals.

Acknowledgments: The authors would like to thank the National Science Council of the Republic of China, Taiwan, for financially supporting this research under Contract No. NSC 101-2221-M-252-011. Wallace Academic Writing is appreciated for editorial assistance.

Author Contributions: C.J.H. and L.M.Y. designed the study; L.W.H., L.S.D. and L.C.F. performed the research; H.S.L. provided materials; C.J.H. wrote the first draft of the manuscript. All authors read and approved the final manuscript.

Conflicts of Interest: The authors declare no conflict of interest.

\section{References}

1. Stocker, P.; Lesgards, J.F.; Vidal, N.; Chalier, F.; Prost, M. ESR study of a biological assay on whole blood: Antioxidant efficiency of various vitamins. Biochem. Biophys. Acta 2003, 1621, 1-8. [CrossRef]

2. Miliauskas, G.; Venskutonis, P.R.; van Beck, T.A. Screening of radical scavenging activity of some medicinal and aromatic plant extracts. Food Chem. 2004, 85, 231-237. [CrossRef]

3. Tachakittirungrod, S.; Okonogi, S.; Colwwanapoonpohn, S. Study on antioxidant activity of certain plants in Thailand: Mechanism of antioxidant action of guava leaf extract. Food Chem. 2007, 103, 381-388. [CrossRef]

4. Jayaprakasha, G.K.; Rao, J.L.; Sakariah, K.K. Antioxidant activities of flavidin in different in vitro model systems. Bioorg. Med. Chem. 2004, 12, 5141-5146. [CrossRef] [PubMed]

5. Moure, A.; Cruz, J.M.; Franco, D.; Dominguez, J.M.; Sineiro, J.; Dominguez, H. Natural antioxidants from residual sources. Food Chem. 2001, 72, 145-171. [CrossRef]

6. Braca, A.; Sortino, C.; Politi, M.; Morelli, I.; Mendez, J. Antioxidant activity of flavonoids from Licania licaniaeflora. J. Ethnopharmacol. 2002, 79, 379-381. [CrossRef]

7. Montoro, P.; Braca, A.; Pizza, C.; de Tommasi, N. Structure-antioxidant activity relationships of flavonoids isolated from different plant species. Food Chem. 2005, 92, 349-355. [CrossRef]

8. Kayano, S.; Kikuzaki, H.; Fukutsuka, N.; Mitani, T.; Nakatain, N. Antioxidant activity of prune (Prunus domestica L.) Constituenys and a new synergist. J. Agric. Food. Chem. 2002, 50, 3708-3712. [CrossRef] [PubMed]

9. Kim, D.W.; Son, K.H.; Chang, K.B.; Kang, S.S.; Kim, H.P. Anti-inflammatory activity of Sedum Kamtschaticum. J. Ethnopharmacol. 2004, 90, 409-414. [CrossRef] [PubMed]

10. De Souza, G.C.; Haas, A.P.; Poser, G.L.; Schapoval, E.E.; Elisabetsky, E. Ethnopharmacological studies of antimicrobial remedies in the south of Brazil. J. Ethnopharmacol. 2004, 90, 135-143. [CrossRef] [PubMed]

11. Kan, W.S. Manual of Vegetable Drugs in Taiwan; The Chinese Medicine Publishing Inc.: Taipei, Taiwan, 1968; Volume 3, p. 30.

12. Yoshikawa, M.; Shimada, H.; Shimoda, H.; Murakami, N.; Yamahara, J.; Matsuda, H. Bioactive constituents of Chinese natural medicines. II. Rhodiocyanosides A and B from the underground part of Rhodiola (R.) quadrifida (PALL) FISCH. Et MEY. (Crassulaceae). Chem. Pharm. Bull. 1996, 44, 2086-2091. [CrossRef] [PubMed]

13. He, A.; Wang, M.; Hao, H.; Zhang, D.; Lee, K.H. Hepatoprotective triterpenes from Sedum sarmentosum. Phtochemistry 1998, 49, 2607-2610. [CrossRef]

14. Morikawa, T.; Ninomiya, K.; Zhang, Y.; Yamada, T.; Nakamura, S.; Matsuda, H.; Muraoka, O.; Hayakawa, T.; Yoshikawa, M. Flavonol glycosides with lipid accumulation inhibitory activity from Sedum sarmentosum. Phytochem. Lett 2012, 5, 53-58. [CrossRef]

15. Kang, T.H.; Pae, H.O.; Yoo, J.C.; Kim, N.Y.; Kim, Y.C.; Ko, G.I.; Chung, H.T. Antiproliferative effects of alkaloids from Sedum sarmentosum on murine and human hepatoma cell limes. J. Ethnopharmacol. 2000, 70, 177-182. [CrossRef] 
16. Zhang, Y.; Morikawa, T.; Nakamura, S.; Ninomiya, K.; Matsuda, H.; Muraoka, O.; Yoshikawa, M. Bioactive constituents from Chinese natural medicines. XXV. New flavonol bisdesmosides, sarmenosides I, II, III and IV, with hepato- protective activity from Sedum sarmentosum. Heterocycles 2007, 71, 1565-1567.

17. De Melo, G.O.; Malvar, D.C.; Vanderlinde, F.A.; Pires, P.A.; Côrtes, W.S.; Filho, G.P.; Muzitano, M.F.; Kaiser, C.R.; Costa, S.S. Phytochemical and pharmacological study of Sedum dendroideun leaf juice. J. Ethnopharmacol. 2005, 102, 217-220. [CrossRef] [PubMed]

18. Yoshikawa, M.; Morikawa, T.; Zhang, Y.; Nakamura, S.; Muraoka, O.; Matsuda, H. Megastigmanes and their glucosides from the whole plant of Sedum sarmentosum. J. Nat. Prod. 2007, 70, 575-583. [CrossRef] [PubMed]

19. Yoshikawa, M.; Shimada, H.; Horikawa, S.; Murakami, T.; Shimada, H.; Yamahara, J.; Matsuda, H. Bioactive Constituents of Chinese Natural Medicones. IV. Rhodiolae radix. (2): On the Histamine Release Inhibitor from the Underground Part of Rhodiola sacra (PRAIN ex. HAMET) S. H. Fu (Crassulaceae): Chemical Structure of Rhodiocyanoside D and Sacranosides A and B. Chem. Pharm. Bull. 1997, 45, 1498-1503. [PubMed]

20. Nishida, R.; Rothschild, M.; Mummery, R. Acyanoglucoside, sarmentosin, from the magpie moth, Abraxas grossulariata, geometridae: Lepidoptera. Phytochemistry 1994, 36, 37-38. [CrossRef]

21. Yang, Z.; Tu, Y.; Baldermann, S.; Dong, F.; Xu, Y.; Watanabe, N. Isolation and identification of compounds from the ethanolic extract of flowers of the tea (Camellia sinensis) plant and their contribution to the antioxidant capacity. LWT-Food Sci. Technol. 2009, 42, 1439-1443. [CrossRef]

22. Le Gall, G.; Dupont, M.S.; Mellon, F.A.; Davis, A.L.; Collins, G.J.; Verhoeyen, M.E. Characterization and content of flavonoid glycosides in genetically modified tomato (Lycopersicon esculentum) fruits. J. Agric. Food. Chem. 2003, 51, 2438-2446. [CrossRef] [PubMed]

23. Velozo, L.S.M.; Ferreira, M.J.P.; Santos, M.I.S.; Moreira, D.L.; Guimarães, E.F.; Emerenciano, V.P.; Kaplan, M.A.C. C-glycosyl flavones from Peperomia blanda. Fitoterapia 2009, 80, 119-122. [CrossRef] [PubMed]

24. Taguchi, K.; Yoshioka, I.; Yamasaki, K.; Kim, I.H. Studies on the Constituents of Gastrodia elata. Chem. Pharm. Bull. 1981, 29, 55-62. [CrossRef]

25. Cao, G.; Sofic, E.; Prior, R.L. Antioxidant and prooxidant behavior of flavonoids: Structure-activity relationships. Free Radic. Biol. Med. 1996, 22, 749-760. [CrossRef]

26. Wolfe, K.L.; Liu, R.H. Structure-activity relationships of flavonoids in the cellular antioxidant activity assay. J. Agric. Food. Chem. 2008, 56, 8404-8411. [CrossRef] [PubMed]

27. Markham, K.R.; Ternai, B.; Stanley, R.; Geiger, H.; Mabry, T.J. Carbon-13 studies of flavonoids-III. Naturally occurring flavonoid glycosides and their acylated derivatives. Tetrahedron 1978, 34, 1389-1397. [CrossRef]

28. Wiedenfeld, H.; Cetto, A.A.; Amador, C.P. Flavonol glycosides from Equisetum myriochetum. Biochem. Syst. Ecol. 2000, 28, 395-397. [CrossRef]

29. Zhang, Z.; Ma, P.; Xu, Y. Preventive effect of gastrodin on cognitive decline after cardiac surgery with cardiopulmonary bypass: A bouble-blind, randomized controlled study. J. Huazhong Univ. Sci. Technol. 2011, 31, 120-127. [CrossRef] [PubMed]

30. Zhang, Q.; Yang, Y.M.; Yu, G.Y. Effect of gastrodin injection on blood pressure and vasoactive substances in treatment of old patients with refractory hypertension: A randomized controlled trial. J. Chin. Integr. Med. 2008, 6, 695-699. [CrossRef] [PubMed]

31. Chen, J.H.; Liau, B.C.; Jong, T.T.; Chang, C.M.J. Extraction and Purification of Flavanone Glycosides and Kaemferol Glycosides from Defatted Camellia Oleifera Seeds by Salting-Out Using Hydrophilic Isopropanol. Sep. Purif. Technol. 2009, 67, 31-37. [CrossRef]

32. Chen, J.H.; Wu, H.Y.; Liau, B.C.; Chang, C.M.J.; Jong, T.T.; Wu, L.C. Identification and Evaluation of Antioxidants Defatted Camellia Oleifera Seeds by Isopropanol Salting-Out Pretreatment. Food Chem. 2010, 121, 1246-1254. [CrossRef]

33. Lee, J.C.; Kim, H.R.; Kim, J.; Jang, Y.S. Antioxidant property of an enthanol extract of the stem of Opuntia ficus-indica var. saboten. J. Agric. Food. Chem. 2002, 50, 6490-6496. [CrossRef] [PubMed]

34. Huang, D.; Ou, B.; Hampsch-Woodill, M.; Flanagan, J.A.; Prior, R.I. High- throughput assay of oxygen radical absorbance capacity (ROAC) using a multichannel liquid handling system coupled with a microplate fluorescence reader in 96-well format. J. Agric. Food. Chem. 2002, 50, 4437-4444. [CrossRef] [PubMed]

35. Lim, Y.Y.; Lim, T.T.; Tee, J.J. Antioxidant properties of several tropical fruits: A comparative study. Food Chem. 2007, 103, 1003-1008. [CrossRef] 
36. Mandal, S.; Hazra, B.; Sarkar, R.; Biswas, S.; Mandal, N. Assessment of the Antioxidant and Reactive Oxygen Species Scavenging of Methanolic Extract of Caesalpinia crista Leaf. Evid. Based Complement. Altern. Med. 2011, 2011, 173768.

37. Ruch, R.J.; Cheng, S.J.; Klavning, J.E. Prevention of cytotoxicity and inhibition of intercellular communication by antioxidant catechins isolated from Chinese green tea. Carcinogens 1989, 10, 1003-1008. [CrossRef]

Sample Availability: Not Available.

(c) 2016 by the authors; licensee MDPI, Basel, Switzerland. This article is an open access article distributed under the terms and conditions of the Creative Commons Attribution (CC-BY) license (http://creativecommons.org/licenses/by/4.0/). 